\title{
Effects of feedstocks on the process integration of biohydrogen production
}

\author{
Domenico Foglia • Walter Wukovits • \\ Anton Friedl · Mattias Ljunggren · Guido Zacchi • \\ Krzysztof Urbaniec $\cdot$ Mariusz Markowski
}

Received: 15 November 2010/ Accepted: 26 January 2011/Published online: 17 February 2011

(C) The Author(s) 2011. This article is published with open access at Springerlink.com

\begin{abstract}
Future production of hydrogen must be sustainable. To obtain it, renewable resources have to be employed for its production. Fermentation of biomasses could be a viable way. The process evaluated is a two-step fermentation to produce hydrogen from biomass. Process options with barley straws, PSP, and thick juice as feedstocks have been compared on the basis of process balances. Aspen Plus has been used to calculate mass and energy balances taking into account the integration of the process. Results show that the production of hydrogen as energy carrier is technically feasible with all the considered feedstocks and thanks to heat integration, second generation biomass (PSP and barley straws) are competitive with food crops (thick juice).
\end{abstract}

Keywords Biohydrogen - Fermentation · Aspen Plus · Process simulation $\cdot$ Process integration

\section{Introduction}

Hydrogen is a carbon-free energy carrier, which at the moment seems to be the only solution for "zero emissions"

This article is based on presentation at PRES 2010 conference in Prague.

D. Foglia $(\bowtie) \cdot$ W. Wukovits · A. Friedl

Vienna University of Technology, Getreidemarkt 9/166-2, 1060 Vienna, Austria

e-mail:dfoglia@mail.tuwien.ac.at

M. Ljunggren · G. Zacchi

Lund University, P. O. Box 124, SE-221 00, Lund, Sweden

K. Urbaniec $\cdot$ M. Markowski

Warsaw University of Technology, Plock Campus,

09-402 Plock, Poland long range vehicles. At the moment a major drawback is the economic and environmental cost of hydrogen production. In fact, hydrogen is currently produced almost exclusively from fossil fuels $\left(\mathrm{CH}_{4}\right.$ reforming and carbon gasification) (Levin et al. 2004). This means that without carbon capture and sequestration (CCS), a hydrogen production facility would produce comparable $\mathrm{CO}_{2}$ emissions as the use of fossil fuels in conventional combustion engines.

Fermentation of biomass residues and second generation biomass is a possible way to enable a sustainable production of hydrogen. Compared to other big centralized systems, the advantage connected to fermentative hydrogen production is mainly local integration on small scale. That's possible due to the adaptation to different types of feedstock, the use of effluents as fertilizers, and the reduction of economical and environmental impact of fuel transport.

A possible way for the biological production of hydrogen from biomass is a two-stage bioprocess investigated in HYVOLUTION project (Stolten 2010).

The proposed process consists of a thermophilic fermentation (THF) step to produce hydrogen, $\mathrm{CO}_{2}$, and organic acids followed by a photo-heterotrophic fermentation (PHF), in which the organic acids are converted to more hydrogen and $\mathrm{CO}_{2}$ (Claassen and de Vrije 2006). The project involves also the evaluation of different pretreatment (PTR) processes for different biomasses, as well as proper gas-upgrading systems. The goal of the HYVOLUTION project is to produce a blue print of a future 2 MW hydrogen plant.

\section{Goal and scope}

Process simulation is a fundamental task of the research path of HYVOLUTION project, since it solves the 
balances necessary for the correct dimensioning of the unit operations, and, consequently, for the economic (Ljunggren and Zacchi 2010), exergetic (Modarresi et al. 2009), and environmental evaluations (Ochs and Ahrer 2010). In the project, it is used as a tool for the development and optimization of the overall process as well as to identify bottlenecks not obvious during the experimental investigation and improvement of single process steps.

The HYVOLUTION process can be adapted to many different types of feedstock (Claassen and de Vrije 2009). Residues and co-products of agro-industries and from farming have been considered as potential feedstocks.

The purpose of this study has been to investigate the influence of various feedstocks - potato steam peels (PSP), thick juice, and barley straw-on the energy and water demand of the two-stage biohydrogen process. These feedstocks are the best performing on a biomass technical suitability index for three types of feedstocks: starch based, sucrose based, and ligno-cellulose based (Panagiotopoulos and Bakker 2008; Panagiotopoulos et al. 2010).

Partners showed that an advantageous utilization of the available amount of the feedstocks considered in this article can cover $3.7 \mathrm{MtH}_{2} / \mathrm{y}$ in the EU25 (Karaoglanoglou et al. 2008) equivalent to $12.8 \mathrm{GW}$ of applied thermal power.

Compared to previous study (Foglia et al. 2010), this article extends considered feedstocks options by including barley straw and updates process steps with improved process parameters.

\section{Process description and modeling}

The process consists of four main steps: PTR, THF, photo(heterotrophic) fermentation, and gas upgrading (Fig. 1).

The process flowsheet has been implemented in the simulation program Aspen Plus ${ }^{\circledR}$ (V7.1, Aspen Technology, Inc., Burlington, USA, 2008) which has been used to solve the mass and energy balances. Components and physical properties are obtained from the Aspen Plus ${ }^{\circledR}$ component database and NREL's databank on biomass components (Wooley and Putsche 1996).

The involved electrolyte equilibrium has been considered during simulation, including all dissociating components and involved ionic species, to be able to calculate the $\mathrm{pH}$ of process streams, to obtain the correct carbon dioxide content of the raw gas stream, and to control the effects of recirculation on the osmolality of the fermentation broth. The thermodynamic model "ElecNRTL" has been used to calculate the vapor-liquid equilibrium in all unit operations.

In this study, the conversions of substrates in the fermentation steps have been assumed as equal for all the different feedstocks under consideration, to enable a comparison of the feedstock options independent from experimental results in the fermentation steps. The applied values of substrate conversion represent optimistic, but feasible parameters. They are close to experimental results based on larger scale fermentation (5-60 L) and have been chosen after discussion with the involved partners. The main parameters of HYVOLUTION process are summarized in Table 1.

\section{PTR of feedstocks}

Depending on the type of biomass processed, pretreatment is used to convert the carbohydrates in the biomass to oligo- and monomeric sugars usable in the THF step.

The assumed compositions of the different feedstocks are summarized in Table 2.

In the analyzed cases, for PSP a standard process of liquefaction and saccharification has been used, while for barley straw a mild-acid PTR has been considered. Thick juice does not require PTR, since it is a biomass in which sugar (sucrose) is directly available for fermentation.
Fig. 1 Scheme of HYVOLUTION process

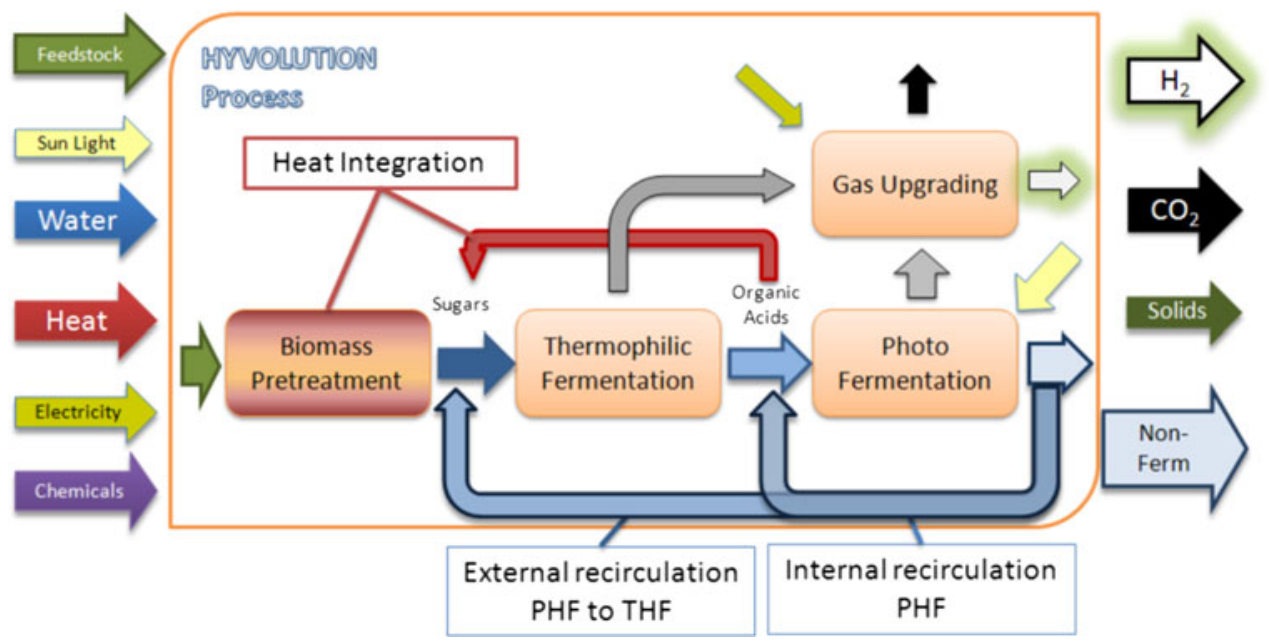


Table 1 Basic settings for PTR, THF, and PHF

\begin{tabular}{|c|c|}
\hline Parameter & Values \\
\hline Plant capacity & $\begin{array}{l}60 \mathrm{~kg} / \mathrm{h} \text { hydrogen, } 97 \% \\
\text { (vol) }\end{array}$ \\
\hline Feedstock & $\begin{array}{l}\text { PSP, thick juice, and barley } \\
\text { straw }\end{array}$ \\
\hline \multicolumn{2}{|l|}{$P T R$} \\
\hline PSP: starch conversion to sugars & $90 \%$ (wt) \\
\hline PSP: reactor temperature & $90^{\circ} \mathrm{C}$ \\
\hline PSP: sugar losses washing step & $5 \%(w t)$ \\
\hline $\begin{array}{l}\text { Barley straw: cellulose conversion to } \\
\text { sugars }\end{array}$ & $78 \%(w t)$ \\
\hline $\begin{array}{l}\text { Barley straw: hemi-cellulose conversion } \\
\text { to sugars }\end{array}$ & $44 \%$ (wt) \\
\hline Barley straw: reactor temperature & $180^{\circ} \mathrm{C}$ \\
\hline $\begin{array}{l}\text { Barley straw: sugar losses filtering step } \\
\text { THF }\end{array}$ & $10 \%$ (wt) \\
\hline Sugar conversion to $\mathrm{H}_{2}$ in THF & $80 \%(w t)$ \\
\hline Sugar conversion to cell mass in $\mathrm{THF}$ & $15 \%(w t)$ \\
\hline Unconverted sugars & $5 \%(w t)$ \\
\hline Temperature THF & $70^{\circ} \mathrm{C}$ \\
\hline $\mathrm{pH}$ THF & 6.5 \\
\hline Substrate concentration THF & $10 \mathrm{~g} / \mathrm{l}$ sugar \\
\hline \multicolumn{2}{|l|}{ PHF } \\
\hline Acetic acid conversion to $\mathrm{H}_{2}$ in PHF & $60 \%(w t)$ \\
\hline $\begin{array}{l}\text { Acetic acid conversion to cell mass in } \\
\text { PHF }\end{array}$ & $15 \%(w t)$ \\
\hline Unconverted acetic acid & $25 \%(w t)$ \\
\hline Temperature PHF & $30^{\circ} \mathrm{C}$ \\
\hline pH PHF & 7.3 \\
\hline Substrate concentration PHF & $40 \mathrm{mM}$ acetic acid \\
\hline
\end{tabular}

Table 2 Assumed composition of low starch PSP, thick juice, and barley straw

\begin{tabular}{lclc}
\hline Components & PSP & Thick juice & Barley straw \\
\hline Water (\%wt) & 86.6 & 28.5 & 8.9 \\
Dry matter (dm) (\%wt) & 13.4 & 71.5 & 91.9 \\
Starch (\%wt dm) & 34.0 & - & - \\
Sucrose (\%wt dm) & - & 92.0 & - \\
Cellulose (\%wt dm) & 24.7 & - & 38.9 \\
Hemicellulose & & & \\
Xylan (\%wt dm) & 2.3 & - & 23.7 \\
Galactan (\%wt dm) & 0.1 & - & 1.3 \\
Arabinan (\%wt dm) & 0.2 & - & 2.3 \\
Lignin (\%wt dm) & 11.4 & - & 22.7 \\
Ashes (Sol. and Insol.) (\%wt dm) & 8.2 & 2.6 & 9.0 \\
Pectin (\%wt dm) & 2.3 & 5.4 & - \\
Protein (\%wt dm) & 16.8 & - & 2.1 \\
\hline
\end{tabular}

In the model presented in Fig. 2 a stream multiplier unit (FEEDM) follows the input stream (FEED) to scale the process to the same hydrogen production flows.

The other flows (dilution water, chemical demands, etc.) are scaled automatically with the feed flow by the use of calculator blocks.

\section{PTR of PSP}

The PTR of PSP is a standard liquefaction-saccharification process performed at temperatures of 90 and $60^{\circ} \mathrm{C}$, respectively. The flowsheet of the process is represented in Fig. 3.

The PSP is first mixed with $\alpha$-amylase in a mashing tank (PR-MASH) and then heated to $90^{\circ} \mathrm{C}$ by direct steam (PR-STEA1). The mixture is introduced into the liquefaction reactor (PR-LIQU), where starch is converted to oligo-saccharides. After liquefaction, glucoamylase is added and the saccharification (PR-SACC) is carried out at a temperature of $60^{\circ} \mathrm{C}$. The enzyme loads of $\alpha$-amylase and glucoamylase are assumed to be 0.50 and $0.65 \mathrm{~kg}$ enzyme/t starch, respectively. During PTR, $90 \%$ of the starch is assumed to be broken down to monomeric and oligomeric saccharides, of which $97 \%$ is monomeric glucose. The data on process conditions and yields in PTR have been based on information from Chaplin and Bucke (1990).

After the saccharification step, a combined filtration and washing unit removes solid material such as cellulose and lignin. This is carried out in a two-step counter-current process using rotating-drum vacuum filters. The used washing and filtration parameters have been taken from Grähs (1976), who stated the removal of $95 \%$ of the solids from the raw stream and a dry mater content of the resulting solid stream of $65 \mathrm{wt} \%$. The substrate losses in the solid stream (PR-DRYER) amount to about $5 \%$ of the pre-filtered stream. The filtrated stream (PR-WS-2A) is then fed to the THF.

\section{Mild-acid PTR of barley straw}

Mobilization of the sugars in lignocelluloses is generally performed by (mild) acid or by alkaline PTR. Both cases have been experimentally investigated in the project. In this article, mild-acid PTR (Fig. 4) has been selected for the simpler process and the better conversion.

Barley straw is first soaked in water (liquid:solid ratio 10:1) and $1 \mathrm{M}$ sulfuric acid solution (2\% w/w d.m.) for $18 \mathrm{~h}$ (PR-MASH). The mixture is then introduced into the high temperature reactor (PR-REACT) which has a retention time of $30 \mathrm{~min}$. The following enzymatic hydrolysis 


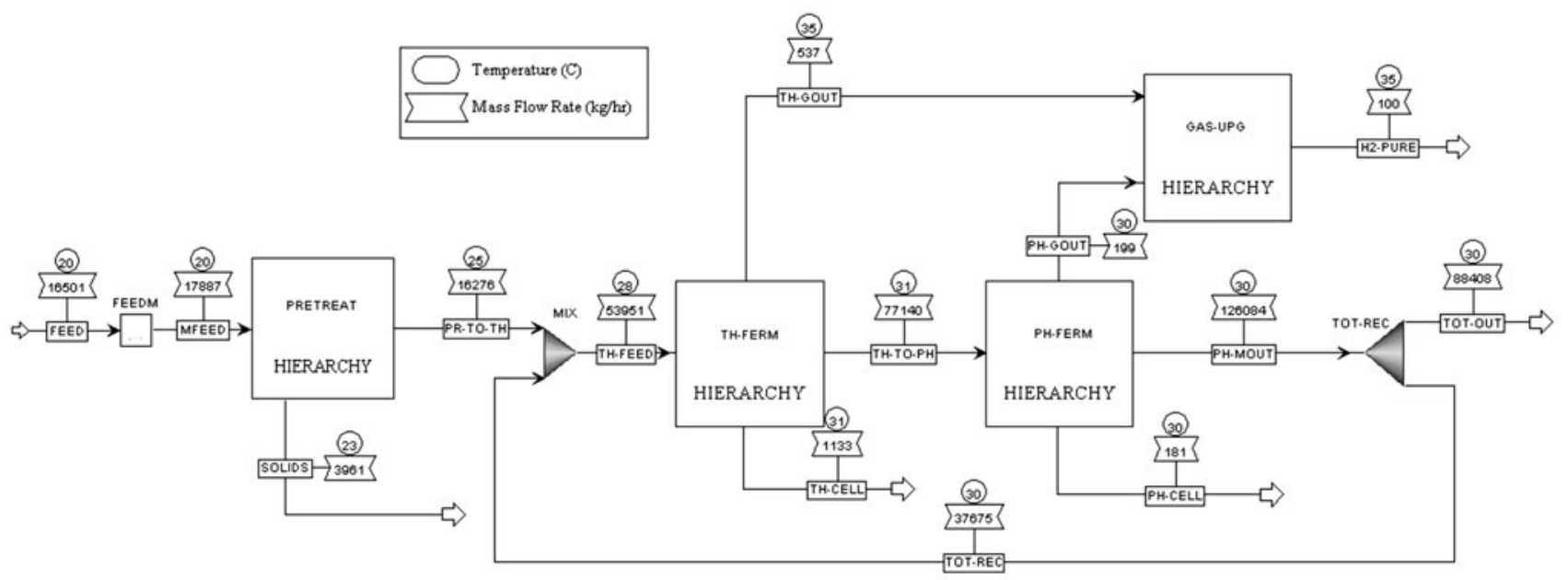

Fig. 2 Aspen Plus flowsheet of HYVOLUTION process (given data refer to the PSP case)
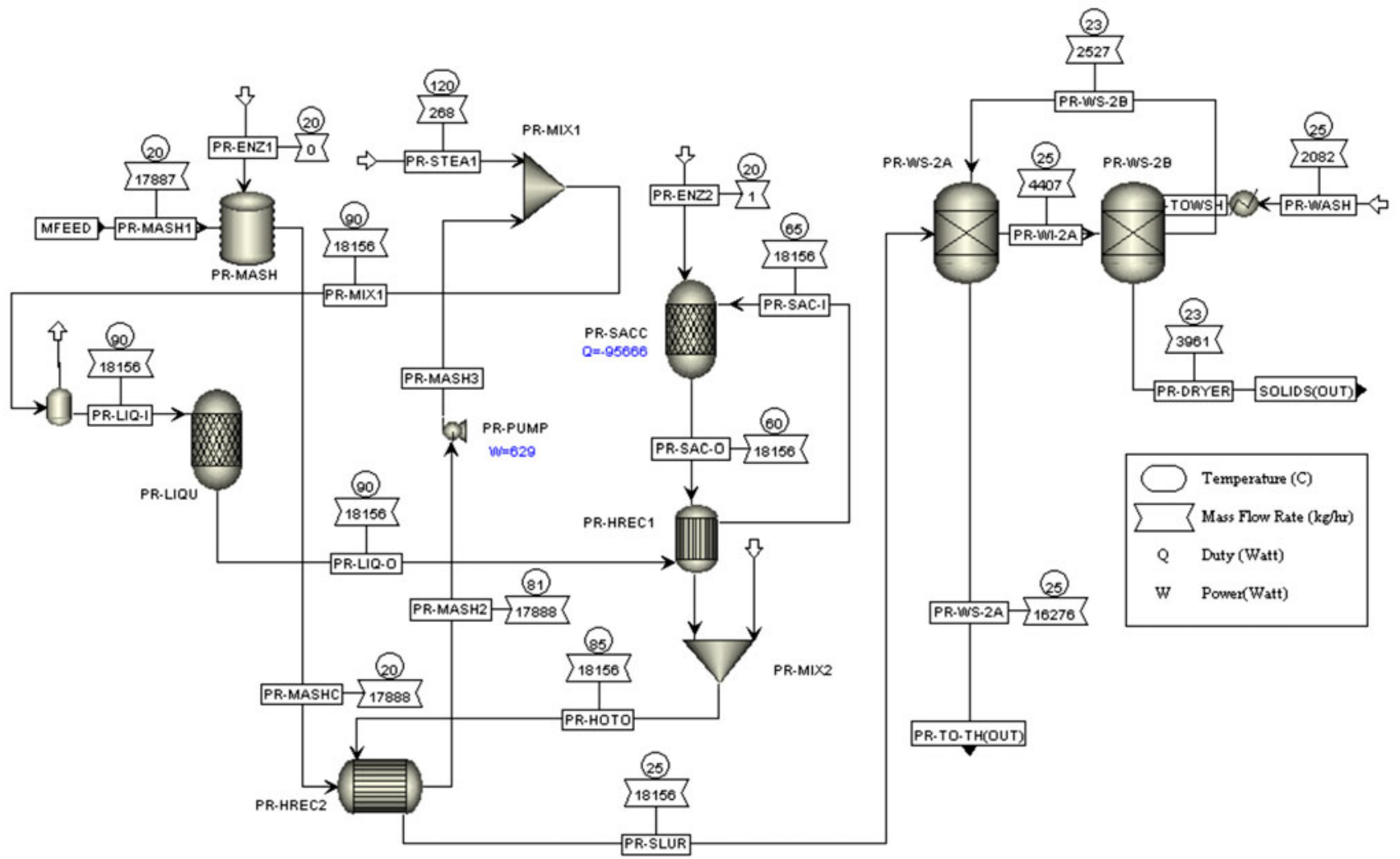

Fig. 3 Aspen Plus flowsheet of PTR of PSP

(PR-SACC) is performed at $50^{\circ} \mathrm{C}$ for $24 \mathrm{~h}$ (Panagiotopoulos et al. 2009).

Project partner's experiments on barley straw PTR showed that high temperatures $\left(160-180^{\circ} \mathrm{C}\right)$ lead to higher yields, but at the cost of higher content of inhibitors. These inhibitors consist in a large part of furfural and in a minor part of HMF (Panagiotopoulos et al. 2010). Since the influence of inhibitor level on THF has not been investigated yet, an additional process step to remove inhibitors has been considered. An effective way to remove inhibitors produced during PTR is an overliming step, followed by reconditioning with acids (Mohagheghi et al. 2006). The calculated osmolality of the obtained substrate stream does not violate the critical osmolality level in the THF step (see below). However, the influence of the overliming step on the 


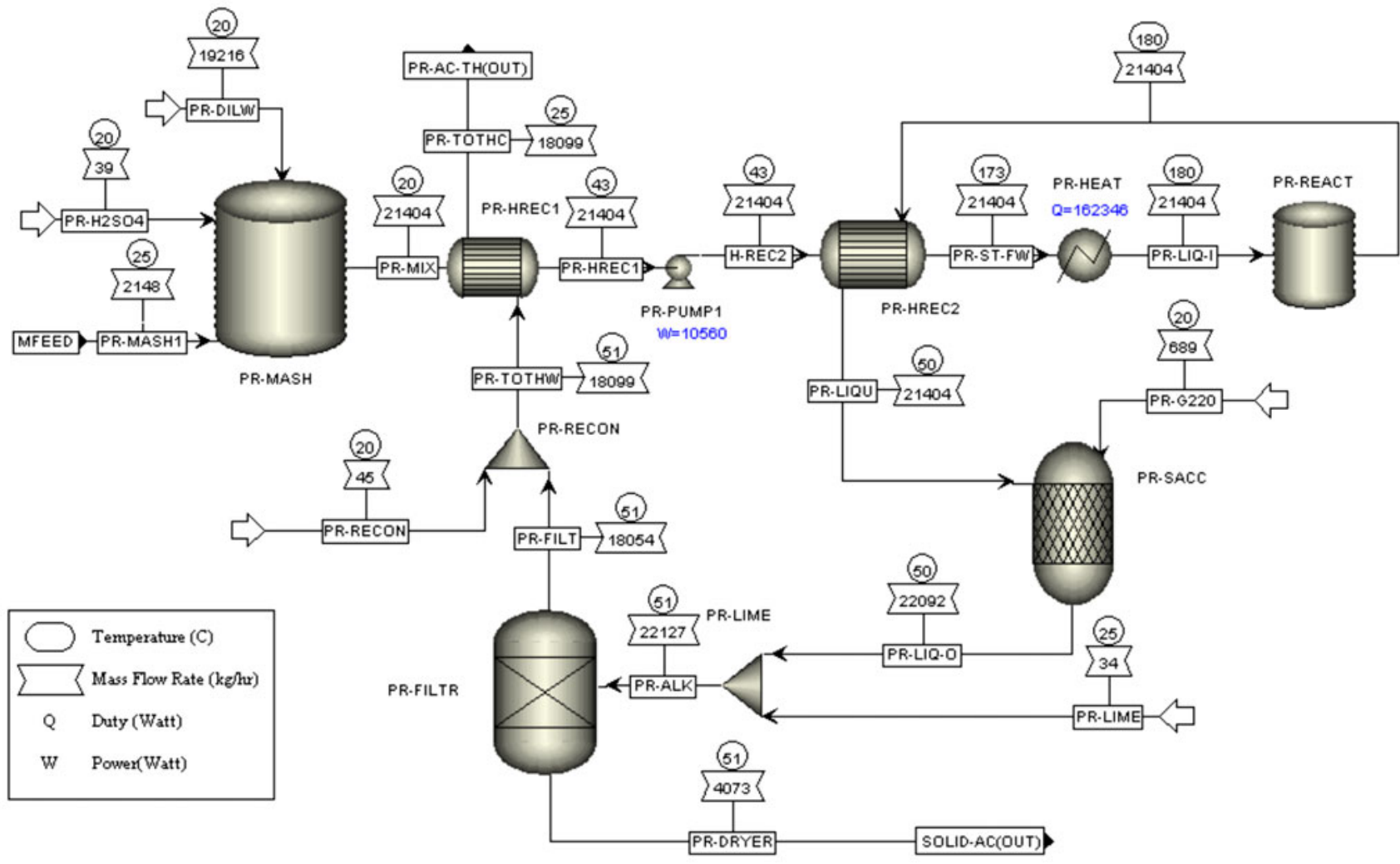

Fig. 4 Aspen Plus flowsheet of mild-acid PTR of barley straw

subsequent fermentation steps has not been investigated experimentally.

The process parameters assumed for the mild-acid PTR are a sulfuric acid load of $2 \%(\mathrm{wt})$ of dried biomass, a temperature of $180^{\circ} \mathrm{C}$, and a $\mathrm{pH}$ of 10 for the overliming step. Cellulase enzymes are added up to a quantity of $30 \mathrm{FPU} / \mathrm{g}$ of dried biomass. Under these conditions, an overall conversion of polysaccharides into monosaccharides of $63.9 \%$ has been reached (Panagiotopoulos et al. 2010).

\section{THF}

The thermophilic (THF) or dark fermentation is an anaerobic fermentation step in which extreme thermophilic bacteria (Caldicellulosiruptor saccharolyticus) are employed at a temperature of $70^{\circ} \mathrm{C}$. In this step, sugars are converted to hydrogen, $\mathrm{CO}_{2}$ and organic acids, preferably acetic acid according to the reactions below:

For pentose:

$3 \mathrm{C}_{5} \mathrm{H}_{10} \mathrm{O}_{5}+5 \mathrm{H}_{2} \mathrm{O} \rightarrow 10 \mathrm{H}_{2}+5 \mathrm{CH}_{3} \mathrm{COOH}+5 \mathrm{CO}_{2}$

For hexose:

$\mathrm{C}_{6} \mathrm{H}_{12} \mathrm{O}_{6}+2 \mathrm{H}_{2} \mathrm{O} \rightarrow 4 \mathrm{H}_{2}+2 \mathrm{CH}_{3} \mathrm{COOH}+2 \mathrm{CO}_{2}$

For sucrose:
$\mathrm{C}_{12} \mathrm{H}_{22} \mathrm{O}_{11}+5 \mathrm{H}_{2} \mathrm{O} \rightarrow 8 \mathrm{H}_{2}+4 \mathrm{CH}_{3} \mathrm{COOH}+4 \mathrm{CO}_{2}$

The yields and conversions, as well as other important parameters, for the base cases are presented in Table 1 and are based on feasible assumptions discussed with partners within the EU-project HYVOLUTION.

The fermentation works best in continuous operation at low substrate concentration of $10 \mathrm{~g} / \mathrm{l}$ of sugars and $\mathrm{pH}$ of 6.5. Dilution water is assumed to be at $20^{\circ} \mathrm{C}$. To maintain the $\mathrm{pH}$ constant, an automated $\mathrm{pH}$ controller is used, using alkaline $(\mathrm{KOH})$ as base to adjust changes in $\mathrm{pH}$, caused by the formation of organic acids during the fermentation step.

Caldicellulosiruptor saccharolyticus suffers of inhibition with increasing hydrogen partial pressure (Willquist et al. 2009). To avoid hydrogen inhibition vacuum is applied to the thermophilic fermentor $(0.55$ bar $)$ to lower the hydrogen partial pressure and improve hydrogen desorption from fermentation broth.

The flowsheet of the model of the thermophilic fermentor is shown in Fig. 5. Unit operation TH-DIL is used to merge the substrate stream coming from PTR (THPREC), the dilution water stream and chemicals $(\mathrm{KOH}$, buffer) streams.

The feed stream is preheated with the reactor effluent (TH-HEXHP) and then heated (TH-PREH) to reach the 


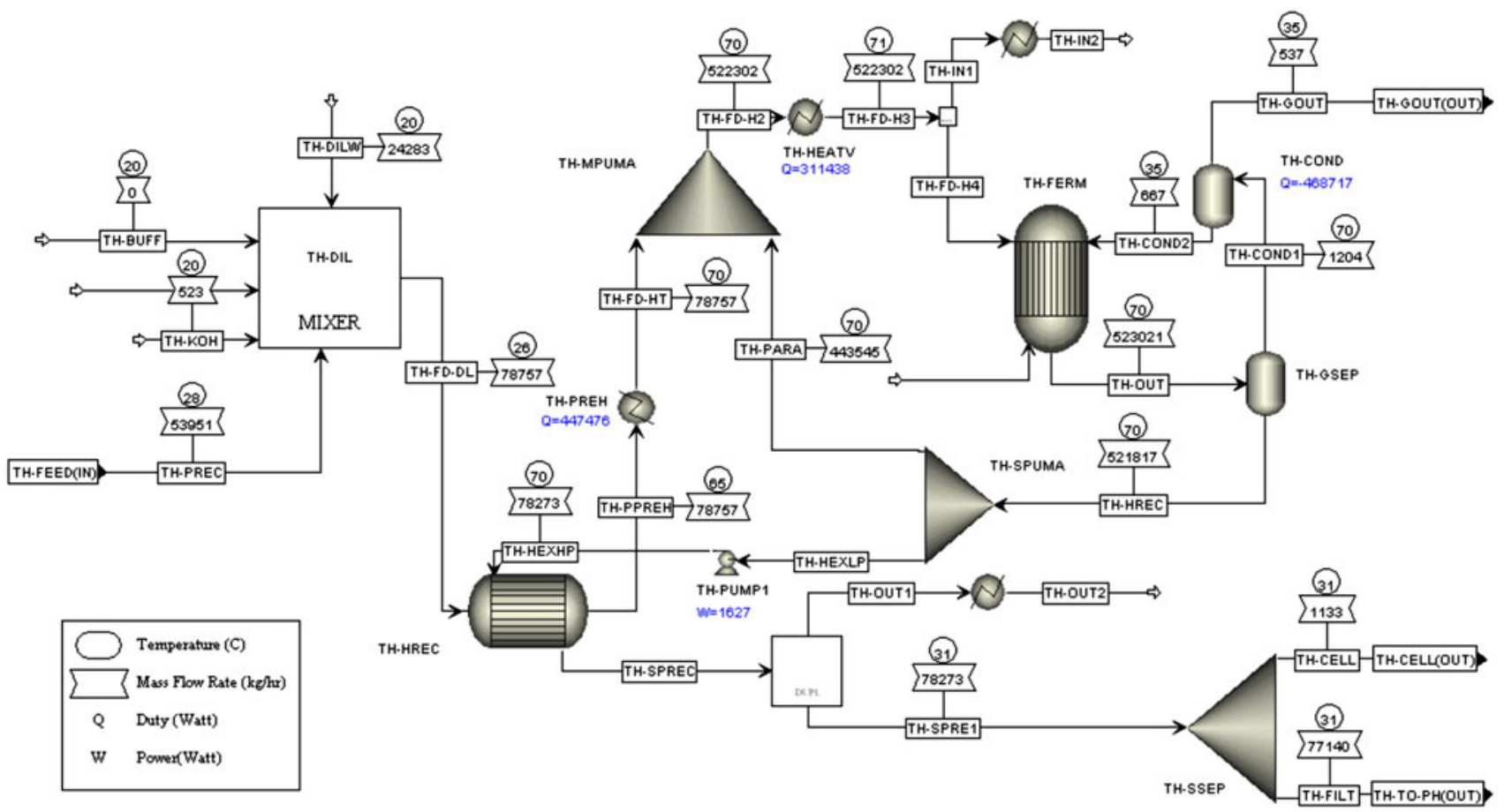

Fig. 5 Aspen Plus flowsheet of THF (given data refer to the PSP case)

necessary $70^{\circ} \mathrm{C}$ before entering the thermophilic fermentor (TH-FERM). Here the stream is mixed with the pumparound stream (TH-PARA) to be fed to the fermentor unit (TH-FERM). Before the fermentor, a heater (TH-HEATV) is inserted to maintain the temperature at $70^{\circ} \mathrm{C}$ in the fermentor. The flash unit TH-GSEP is used to calculate the vapor-liquid equilibrium of the fermentor effluent, since this is not possible in the selected reactor model. The resulting gas stream enters a second flash unit (TH-COND) to recover most of the water lost during evaporation. After the heat exchange with the fermentor feed, the liquid effluent is directed to the solid separator (TH-SSEP) to separate the cell mass (TH-CELL) produced in the fermentation step before entering to the photo fermentor.

The osmotic pressure of the fermentation must be controlled, since a critical limit of $0.30 \mathrm{Osmol} / \mathrm{kg} \mathrm{H}_{2} \mathrm{O}$ should not be exceeded (Willquist et al. 2009). Aspen Plus does not include the osmolality value as a property set. The osmolality of the streams can be simply calculated by summing the concentrations of the contributing dissociated and not dissociated species of the solution, reported in the stream results when "true species approach" is selected. To enable calculation of the osmolality of the fermentation broth, the input and output streams (TH-IN1 and THOUT1) of the fermentor are duplicated to change the operation mode of the electrolyte thermodynamic model from "apparent component approach" to "true species approach". A placebo heater unit is included after the block to force Aspen Plus to re-calculate the stream properties with the new settings.

\section{PHF}

The photo-fermentation step is a light-driven process, which converts the organic acids to hydrogen and $\mathrm{CO}_{2}$ (Barbosa et al. 2001).

The photo-synthetic bacterium Rhodobacter sphaeroides O.U. 001 is used for the photo fermentation. The reactor operates best around $30^{\circ} \mathrm{C}$ and works at a substrate concentration of $40 \mathrm{mM}$ with a conversion of $60 \%$ of the theoretical yield according to the following reaction:

$\mathrm{CH}_{3} \mathrm{COOH}+2 \mathrm{H}_{2} \mathrm{O}+$ light $\rightarrow 4 \mathrm{H}_{2}+2 \mathrm{CO}_{2}$.

Depending on geographic parameters tubes or flat panels is the preferred reactor design (Tredici and Zittelli 1998; Eroglu et al. 2008).

Very low concentration and very high retention time (10 days) are required to operate the fermentor in continuous mode (Ljunggren and Zacchi 2010). This conditions lead to huge volumes and areas required for the fermentor. Due to the dimensions, $\mathrm{pH}$ variations cannot be controlled locally, so a high buffer (potassium phosphate salts) concentration of $20 \mathrm{mM}$ is required in the fermentation broth.

The arrangement of the model of the PHF (Fig. 6) equals the model of the THF step described above. In this step an internal recirculation loop is connected to the inlet 




Fig. 6 Aspen Plus flowsheet of PHF (given data refer to the PSP case)

(PH-SPREC, PH-MREC). The split (PH-SPREC) for the internal recirculation (PH-REC) is placed before the filtration step, while the split for the external recirculation (TOT-REC) (see also section below) is placed after the separation of the produced cell mass (Fig. 2).

Gas upgrading

The produced raw gas from the two fermentation steps contains not only hydrogen, but also a large amount of carbon dioxide as well as some water. To obtain pure hydrogen (assumed to be $97 \%$ per volume) the raw gas is processed in a dedicated gas-upgrading step. Vacuum swing adsorption (VSA) is applied in the actual calculations to upgrade the combined raw gas stream of a flow rate of about $700 \mathrm{Nm}^{3} / \mathrm{h}$, composed in average by $66 \%$ of hydrogen, $28 \%$ of carbon dioxide, and $5 \%$ of water (volume based). VSA has been selected since it is the state of the art method for hydrogen upgrading at small scale as well as because of its flexibility concerning raw gas concentration.

The model of the upgrading step (Fig. 7) includes a vacuum pump (GU-CTHF), required to raise the pressure of the thermophilic raw gas to ambient pressure. Connected to the vacuum pump is a cooler (GU-COOL1) and a condensate separator (GU-GLS1). The following buffer tank (GU-GMIX) is required to equilibrate fluctuation in raw gas flow rate from photo fermentor due to the day-night cycle. The adsorber tanks (GU-VSA) are represented by a simple separation unit model and a valve (GU-VVAC). Thus, the model is not able to provide design parameter for the adsorption process, but is able to evaluate the energy consumption of the gas-upgrading unit (vacuum pumps, blowers). To overcome the pressure drop of the adsorber bed the blower GU-BLOW is included. Vacuum for regeneration of the adsorber is provided by a three-stage compressor (GU-CO2C1/C2/C3) with inter-cooling (GUCOOL3/4/5). Compressors efficiencies have been assumed as $85 \%$ isentropic and $85 \%$ mechanical.

Design parameters for the purification step are a product purity of $97 \%$ hydrogen and $10 \%$ hydrogen losses due to regeneration of the adsorber beds.

\section{Process integration}

Due to increasing costs of water and fees for wastewater discharge, interest in saving water and wastewater has increased (Wenzel et al. 2002). Moreover, areas with high solar exposition (necessary for the photo fermentation) are often water scarce. Reduction of water demand, therefore, is required for technical, ecologic, and economic reasons.

Biomass PTR and the THF are energy intensive process steps. During biomass PTR liquefaction temperatures of 90 and $180^{\circ} \mathrm{C}$ are necessary for PSP and barley straw, respectively. In both cases a high amount of water in the streams needs to be heated up. The THF step requires a temperature of $70^{\circ} \mathrm{C}$ for a sugar stream of $10 \mathrm{~g} / \mathrm{l}$ sugar.

In addition to the high heat demand required to adjust the necessary temperatures, the process involves highly diluted process streams to avoid inhibition of the fermentation steps, resulting in a very high demand of fresh water. 




Fig. 7 Aspen Plus flowsheet of gas upgrading by vacuum swing adsorption (given data refer to the PSP case)

Recirculation of the effluent streams has been identified as the easiest option, in terms of technology and costs, to reduce the water and heat demand of the process. But as shown in previous publications not all routes are practicable. The recirculation of the thermophilic fermentor effluent at $70^{\circ} \mathrm{C}$ would reduce both heat and water demand of the first fermentation step. However, this solution causes a build-up of the acetic acid concentration, increasing strongly the osmotic pressure of the fermentation broth (Foglia et al. 2010). The photo-fermentation effluent can be used for recirculation to reduce the water demand in the photo-fermentation step ("internal recirculation", Fig. 1) but also in the thermophilic fermentor ("external recirculation", Fig. 1) without affecting the composition of the feed stream. Experiments regarding recirculation are still on-going, but first results showed positive outcome to a certain percentage of recirculation. For this reason, internal and external recirculations have been calculated to reduce the amount of dilution water amount required in the fermentation steps by $60 \%$.

Heat exchangers in the PTR and THF steps are introduced to recover heat from the warm outlet streams. The disposition of the heat exchangers has been chosen after different evaluations to minimize the remaining heat demand.

For PSP PTR (Fig. 3), one heat exchanger (PR-HREC2) has been used to recover the heat of the warm outlet of the liquefaction reactor $\left(85^{\circ} \mathrm{C}\right)$ and its cold inlet $\left(25^{\circ} \mathrm{C}\right)$, and another one (PR-HREC1) between the inlet $\left(90^{\circ} \mathrm{C}\right)$ and the outlet $\left(60^{\circ} \mathrm{C}\right)$ of the saccharification step (PR-SACC). For barley straw PTR, one heat exchanger (PR-HREC2) has been added between the high temperature reactor $\left(180^{\circ} \mathrm{C}\right)$ and the saccharification step $\left(50^{\circ} \mathrm{C}\right)$, and a second one (PRHREC1) between the warm PTR outlet $\left(50^{\circ} \mathrm{C}\right)$ and its diluted cold inlet $\left(20^{\circ} \mathrm{C}\right)$. In the THF step a heat exchanger (TH-HREC) is introduced to preheat the cold fermentor inlet with its warm $\left(70^{\circ} \mathrm{C}\right)$ outlet. For all the heat exchangers, a minimum temperature difference of $5^{\circ} \mathrm{C}$ has been implemented between hot/cold streams.

\section{Results and discussion}

To calculate the mass and heat balances of the different feedstock options, the process has been designed to produce $60 \mathrm{~kg} / \mathrm{h}$ of pure hydrogen $(97 \% \mathrm{vol})$ equivalent to $2 \mathrm{MW}$ thermal power.

Simplified mass and energy balances for the three feedstocks are shown in Fig. 8, reporting the most important results, such as biomass consumption, effluent flow rates, dilution water, and heat demand as well as some characteristic process temperatures. For feedstock PSP, further details can be taken from Figs. 2, 3, 5, 6, and 7. Stream mass compositions for all considered feedstocks, PSP, thick juice and barley straw, are summarized in Tables 3, 4, and 5. 
Fig. 8 a, b, and $\mathbf{c}$ Basic mass and heat balances of fully integrated Hyvolution process based on feedstocks PSP (a), thick juice (b), and barley straw (c) assuming reduction of dilution water by recirculation of $60 \%$. The arrows named: "Steam", "Heat", "Preheater" and "Fermentor" (red) correspond to heat duties (MW). The others (blue and white) correspond to mass flows $(\mathrm{t} / \mathrm{h})$ (a) Potato Steam Peels

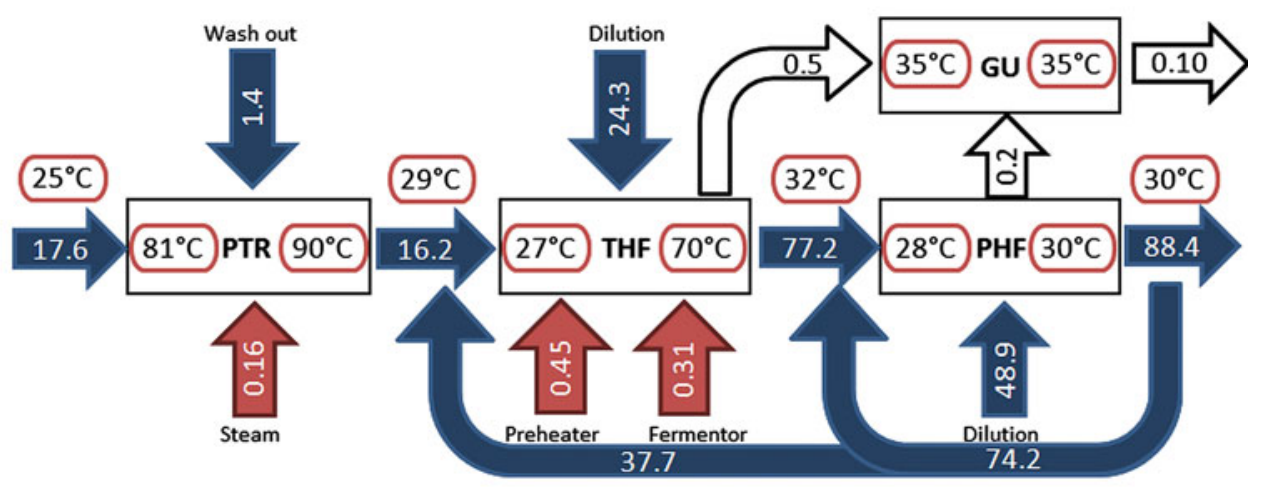

(b) Thick Juice



(c) Barley Straw


("preheater" in Fig. 8) as well as due to covering heat losses in the fermentor caused by evaporation of fermentation broth when applying vacuum ("fermentor" in Fig. 8).

The electric power input required by the gas-upgrading block is constituted by the demand of the three-stage vacuum pump (GU-CO2C1/C2/C3) and the blower (GU-BLOW).

Differences in feedstock flows are mainly caused by the dry matter content of feedstock as well as the content of fermentable carbohydrates and their mobilization during PTR.

From the balances it is evident that even after introduction of effluent recirculation to reduce the amount of dilution water by $60 \%$, the demand of fresh process water at 70 and $90 \mathrm{t} / \mathrm{h}$ is still high. Experimental results will show 
Table 3 PSP_detailed stream table $(\mathrm{kg} / \mathrm{h})$ referring to Fig. 8

\begin{tabular}{|c|c|c|c|c|c|c|c|c|c|c|c|}
\hline & Starch & Cellulose & Hemi-cellulose & $\mathrm{H}_{2} \mathrm{O}$ & Sugars & Acetic acid & $\mathrm{H}_{2}$ & $\mathrm{CO}_{2}$ & Other chemicals & Other solids & Total \\
\hline Feed-stock input & 811 & 588 & 55 & 15386 & - & - & - & - & - & 1047 & 17887 \\
\hline PTR dilution water & - & - & - & 2082 & - & - & - & - & - & - & 2082 \\
\hline PTR solids output & - & 553 & 52 & 2524 & 42 & - & - & - & - & 791 & 3961 \\
\hline PTR output & 62 & 35 & 3 & 15128 & 790 & - & - & - & - & 256 & 16275 \\
\hline THF inlet & 63 & 35 & 3 & 52413 & 810 & 23 & - & 91 & 256 & 256 & 53949 \\
\hline THF dilution water & - & - & - & 24283 & - & - & - & - & - & - & 24283 \\
\hline THF raw gas & - & - & - & 56 & - & - & 28 & 453 & - & - & 537 \\
\hline THF output & 3 & 2 & - & 76093 & 64 & 437 & - & 12 & 513 & 13 & 77136 \\
\hline PHF inlet & 5 & 3 & - & 149443 & 102 & 481 & - & 192 & 1016 & 20 & 151262 \\
\hline PHF dilution water & - & - & - & 48869 & - & - & - & - & - & - & 48869 \\
\hline PHF output & - & - & - & 124777 & 64 & 76 & - & 306 & 857 & 1 & 126080 \\
\hline PHF raw gas & - & - & - & 18 & - & - & 39 & 142 & 0 & - & 199 \\
\hline PHF internal recirc. & 2 & 1 & - & 73350 & 38 & 45 & - & 180 & 504 & 8 & 74126 \\
\hline External recirc. & - & - & - & 37285 & 19 & 23 & - & 91 & 256 & - & 37674 \\
\hline Effluent & - & - & - & 87492 & 45 & 53 & - & 215 & 601 & - & 88405 \\
\hline $\mathrm{CO}_{2}$ rich gas output & - & - & - & 25 & - & - & 7 & 556 & - & - & 587 \\
\hline $\mathrm{H}_{2}$ product gas & - & - & - & - & - & - & 60 & 40 & - & - & 100 \\
\hline
\end{tabular}

Table 4 Thick juice—detailed stream table $(\mathrm{kg} / \mathrm{h})$ referring to Fig. 8

\begin{tabular}{|c|c|c|c|c|c|c|c|c|c|c|c|}
\hline & Starch & Cellulose & Hemi-cellulose & $\mathrm{H}_{2} \mathrm{O}$ & Sugars & Acetic acid & $\mathrm{H}_{2}$ & $\mathrm{CO}_{2}$ & Other chemicals & Other solids & Total \\
\hline Feed-stock input & - & - & - & 316 & 729 & - & - & - & - & 63 & 1108 \\
\hline THF inlet & - & - & - & 43604 & 742 & 26 & - & 106 & 297 & 64 & 44839 \\
\hline THF dilution water & - & - & - & 28886 & - & - & - & - & - & - & 28886 \\
\hline THF raw gas & - & - & - & 56 & - & - & 28 & 466 & - & - & 551 \\
\hline THF output & - & - & - & 72352 & 37 & 441 & - & 12 & 547 & 6 & 73395 \\
\hline PHF inlet & - & - & - & 149835 & 60 & 488 & - & 203 & 1078 & 39 & 151703 \\
\hline PHF dilution water & - & - & - & 51514 & - & - & - & - & - & - & 51514 \\
\hline PHF output & - & - & - & 123680 & 37 & 75 & - & 304 & 848 & 3 & 124946 \\
\hline PHF raw gas & - & - & - & 18 & - & - & 39 & 151 & - & - & 209 \\
\hline PHF internal recirc. & - & - & - & 77483 & 23 & 47 & - & 190 & 532 & 33 & 78308 \\
\hline External recirc. & - & - & - & 43288 & 13 & 26 & - & 106 & 297 & 1 & 43731 \\
\hline Effluent & - & - & - & 80392 & 24 & 49 & - & 197 & 551 & 2 & 81215 \\
\hline $\mathrm{CO}_{2}$ rich gas output & - & - & - & 25 & - & - & 7 & 576 & - & - & 608 \\
\hline $\mathrm{H}_{2}$ product gas & - & - & - & - & - & - & 60 & 41 & - & - & 102 \\
\hline
\end{tabular}

whether a further increase of the recirculation ratio is possible without influencing productivity and conversion in the fermentors. It has to be considered that changing the recirculation settings will influence the temperature profile of the process due to the temperature difference between fresh water and reactor effluents.

Due to the heat integration measures, all the feedstock options are capable of producing a net amount of energy in form of hydrogen. Especially during PTR the additional heat demand is low, resulting in only $160 \mathrm{~kW}$ both for PSP and barley straw. However, due to different flow rates and temperature levels, heat exchanger design and dimensions, as well as conditions of service streams, will differ for the feedstock options, considerably influencing capital and operational costs of the plant options.

Even with heat integration considerable heat input is necessary to provide the fermentor temperature of $70^{\circ} \mathrm{C}$. In fact, besides pre-heating the fermentation broth, a considerable amount of heat is necessary to keep the reactor temperature at $70^{\circ} \mathrm{C}$ under vacuum conditions. This heat expense is necessary to avoid inhibition by high hydrogen partial pressure. 
Table 5 Barley straw-detailed stream table $(\mathrm{kg} / \mathrm{h})$ referring to Fig. 8

\begin{tabular}{|c|c|c|c|c|c|c|c|c|c|c|c|}
\hline & Starch & Cellulose & Hemi-cellulose & $\mathrm{H}_{2} \mathrm{O}$ & Sugars & Acetic acid & $\mathrm{H}_{2}$ & $\mathrm{CO}_{2}$ & Other chemicals & Other solids & Total \\
\hline Feed-stock input & 757 & 461 & 68 & 191 & - & - & - & - & 10 & 661 & 2148 \\
\hline PTR dilution water & - & - & - & 19216 & - & - & - & - & - & - & 19216 \\
\hline PTR solids output & 12263 & 174 & 38 & 2130 & 114 & 50 & - & - & 93 & 1350 & 4073 \\
\hline PTR output & - & - & - & 17260 & 806 & - & - & - & 32 & - & 18098 \\
\hline THF inlet & - & - & - & 54596 & 830 & 23 & - & 92 & 303 & 1 & 55844 \\
\hline THF dilution water & - & - & - & 22471 & - & - & - & - & - & - & 22471 \\
\hline THF raw gas & - & - & - & 30 & 0 & 0 & 28 & 457 & - & - & 515 \\
\hline THF output & - & - & - & 77120 & 78 & 439 & - & 13 & 574 & 3 & 78228 \\
\hline PHF inlet & - & - & - & 149291 & 123 & 483 & - & 191 & 1099 & 31 & 151219 \\
\hline PHF dilution water & - & - & - & 49596 & - & - & - & - & - & - & 49596 \\
\hline PHF output & - & - & - & 126563 & 78 & 77 & - & 312 & 921 & 2 & 127953 \\
\hline PHF raw gas & - & - & - & 13 & - & - & 39 & 139 & - & - & 191 \\
\hline PHF internal recirc. & - & - & - & 72172 & 45 & 44 & - & 178 & 525 & 28 & 72991 \\
\hline External recirc. & - & - & - & 37336 & 23 & 23 & - & 92 & 272 & 1 & 37746 \\
\hline Effluent & - & - & - & 89227 & 55 & 54 & - & 220 & 649 & 2 & 90207 \\
\hline $\mathrm{CO}_{2}$ rich gas output & - & - & - & 24 & - & - & 7 & 556 & - & - & 587 \\
\hline $\mathrm{H}_{2}$ product gas & - & - & - & - & - & - & 60 & 40 & - & - & 100 \\
\hline
\end{tabular}

Table 6 Heat duty of the vacuum stripping in the thermophilic fermentor at different pressure. The raw gas flow is calculated after the condensation step

\begin{tabular}{lllll}
\hline $\begin{array}{l}\text { Fermentor } \\
\text { pressure (bar) }\end{array}$ & $P_{\mathrm{H}_{2}}(\mathrm{kPa})$ & $\begin{array}{l}\text { Vacuum pump } \\
\text { net work }(\mathrm{kW})\end{array}$ & $\begin{array}{l}\text { Heat duty } \\
\text { TH-HEATV }(\mathrm{kW})\end{array}$ & $\begin{array}{l}\text { Raw gas flow } \\
\text { THF }(\mathrm{kmol} / \mathrm{h})\end{array}$ \\
\hline 0.35 & 2.36 & 27 & 2240 & 26.1 \\
0.45 & 8.60 & 20 & 538 & 25.6 \\
0.55 & 14.91 & 16 & 265 & 25.2 \\
0.65 & 21.29 & 12 & 153 & 24.9 \\
0.75 & 27.74 & 8 & 92 & 24.7 \\
0.85 & 34.27 & 5 & 52 & 24.4 \\
\hline
\end{tabular}

Willquist et al. (2009) suggested remaining under a hydrogen partial pressure of $0.10-0.15$ bar when applying inert gas stripping (nitrogen). However, the reduction of partial pressure by stripping with inert gas is not applicable in production scale due to problems in the gas purification step. Also stripping with gaseous carbon dioxide is not applicable, since it causes the osmolality of the thermophilic fermentor to exceed the critical limit, worsening productivities and yields (Willquist et al. 2009).

To decrease the hydrogen partial pressure in the thermophilic fermentor to the maximum of $0.15 \mathrm{bar}$, the absolute pressure has to be decreased to 0.55 bar (see Table 6). Table 6 summarizes the heat duties necessary to keep the fermentor temperature constant at $70^{\circ} \mathrm{C}$ for different fermentor pressures, together with power demand of the vacuum pump and resulting partial pressure. Results show that heat demand is increasing exponentially when approaching boiling conditions at $70^{\circ} \mathrm{C}$. Heat of evaporation can be recovered via condensation step, but hardly reused in the process. It is finally assumed, that with improved reactor design a fermentor pressure of 0.5 bar is sufficient to avoid hydrogen inhibition.

Photo fermentation experimentally runs between 20 and $30^{\circ} \mathrm{C}$, without control of the temperature in this range. It has been observed that-strongly depending on the ambient temperature - the photo fermentation needs rather cooling than heating. Increase in photo-fermentor temperature is, in fact, obtained by solar irradiation, not by external heating. Therefore, the heater block of the photo fermentor (PH-PREH) warms the temperature up to $30^{\circ} \mathrm{C}$ in the simulation model, but the heat demand is not included in the calculation of the overall heat demand of the process, since it is covered by the sun beams.

Thick juice shows the lowest heat demand of all process options caused by the absence of the PTR step. However, thanks to the proper heat integration PSP and barley strawbased processes require just $20 \%$ more heat demand than that of thick juice. This means that also second generation biomass, with a proper process integration, can compete with food crops. 
The hydrogen content of the dry raw gases from the THF and the PHF steps are 57.6 and $85.6 \%$ (volume based), respectively. The difference to the stoichiometric composition shown in Eqs. 1-4 is caused by the varying carbon dioxide solubilities at different $\mathrm{pH}$ and at different temperatures. Due to highly diluted fermentation broth in the PHF step, most of the produced carbon dioxide is dissolved physically, although a slightly higher amount of carbon dioxide is absorbed in the PHF step compared to the THF step due to the higher $\mathrm{pH}$. The high carbon dioxide content in raw gas from the THF step (higher than stoichiometric content) is also caused by the absorbed carbon dioxide in the PHF step which is recirculated to the THF step in the external recirculation stream (compare Table 5) and desorbed due the lower $\mathrm{pH}$ and higher temperature in the THF step.

The demand of electric power is around $100 \mathrm{~kW}$ and it is almost constant for the different feedstock options, since the GU step is processing the same amount of raw gas of almost equal quality.

\section{Conclusions and outlook}

The study presents some problems investigated in the HYVOLUTION project through process simulation. The presented balances are based on the feedstocks barley straw, PSP, and thick juice. A net energy production, in form of hydrogen, seems technically feasible for all considered biomasses. Thick juice has the lowest energy demand, but the other options require just $20 \%$ more heat demand. This means that second generation biomass can compete with food biomass for the hydrogen production.

Improvement of mass and energy balances in terms of feedstock specific productivities and conversion to hydrogen will give a clearer picture on the performance of investigated feedstock options. Furthermore, implementation of large scale experimentally determined process parameters will allow further insight to the feasibility of proposed process and heat integration and play an important role in the final selection of a promising route for HYVOLUTION process.

\begin{abstract}
Acknowledgments We gratefully acknowledge the use of experimental data for modeling feedstock pretreatment based on work performed by project partners Stichting Dienst Landbouwkundig Onderzoek-Food and Biobased Research (former: Wageningen URAgrotechnology and Food Innovations) and National Technical University of Athens. HYVOLUTION project is supported by the European Union's 6th Framework Program on Sustainable Energy Systems (Hyvolution, Contract-No 019825).
\end{abstract}

Open Access This article is distributed under the terms of the Creative Commons Attribution Noncommercial License which permits any noncommercial use, distribution, and reproduction in any medium, provided the original author(s) and source are credited.

\section{References}

Aspen Plus ${ }^{\circledR}$ V7.1 (2008) Aspen Technology, Inc., Burlington, USA

Barbosa MJ, Rocha JMS, Tramper J, Wijffels RH (2001) Acetate as a carbon source for hydrogen production by photosynthetic bacteria. J Biotechnol 85:25-33

Chaplin M, Bucke C (1990) Enzyme technology. Cambridge University Press, Cambridge

Claassen PAM, de Vrije T (2006) Non-thermal production of pure hydrogen from biomass: hyvolution. Int $\mathrm{J}$ Hydrogen Energy 3:1416-1423

Claassen PAM, de Vrije T (2009) Non-thermal production of pure hydrogen from biomass: hyvolution. Chem Eng Trans 18: 333-338

Eroglu I, Tabanoglu A, Gündüz U, Eroglu E, Yücel M (2008) Hydrogen production by Rhodobacter sphaeroides O.U.001 in a flat plate solar bioreactor. Int J Hydrogen Energy 33:531-541

Foglia D, Ljunggren M, Wukovits W, Friedl A, Zacchi G, Urbaniec K, Markowski M (2010) Integration studies on a two-stage fermentation process for the production of biohydrogen. J Clean Prod 18:S72-S80

Grähs LE (1976) Displacement washing of packed beds of cellulose fibres. Swed J Pap 79:123-128

Karaoglanoglou LS, Diamantopoulou LK, Koukios EG (2008) At the crossroads of feasibility and sustainability: building biomass-tobiohydrogen supply chains. In: Proceedings of 16th European biomass conference and exhibition, Valencia, Spain, pp 435-438

Levin DB, Pitt L, Love M (2004) Biohydrogen production: prospects and limitations to practical application. Int $\mathbf{J}$ Hydrogen Energy 29:173-185

Ljunggren M, Zacchi G (2010) Techno-economic evaluation of a twostep biological process for hydrogen production. Biotechnol Progr 26:496-504

Modarresi A, Wukovits W, Friedl A (2009) Effect of process integration on the exergy balance of a process for biological hydrogen production. Chem Eng Trans 18:391-396

Mohagheghi A, Ruth M, Schell DJ (2006) Conditioning hemicellulose hydrolysates for fermentation: effects of overliming $\mathrm{pH}$ on sugar and ethanol yields. Process Biochem 41:1806-1811

Ochs D, Ahrer W (2010) Life cycle analysis of hydrogen production from biomass fermentation. Chem Eng Trans 21:1159-1164

Panagiotopoulos IA, Bakker R (2008) Comparative study of different lignocellulosic feedstocks enzymatic hydrolysis for fermentable substrates production. In: Proceedings of the 16th European biomass conference and e xhibition. Valencia, Spain, pp 1749-1752

Panagiotopoulos IA, Bakker R, Budde M, de Vrije T, Claassen PAM, Koukios EG (2009) Fermentative hydrogen production from pretreated biomass: a comparative study. Bioresour Technol 100: 6331-6338

Panagiotopoulos IA, Koukios E, Bakker R (2010) internal communications

Stolten D (2010) Hydrogen and fuel cells: fundamentals technologies and applications. Wiley, Weinheim, pp 167-189

Tredici MR, Zittelli GC (1998) Efficiency of sunlight utilization: tubular versus flat photobioreactors. Biotechnol Bioeng 57:187-197

Wenzel H, Dunn R, Gottrup L, Kringelum J (2002) Process integration design methods for water conservation and wastewater reduction in industry. Part 3: experience of industrial application. Clean Techn Environ Policy 4(1):16-25

Willquist K, Claassen PAM, van Niel EWJ (2009) Evaluation of the influence of $\mathrm{CO} 2$ on hydrogen production by Caldicellulosiruptor saccharolyticus. Int J Hydrogen Energy 34:4718-4726

Wooley R, Putsche V (1996) Development of an Aspen Plus physical property database for biofuels components. Golden: NRELReport/MP-425-20685 